\title{
Capacitative calcium entry is involved in steroidogenesis in bovine adrenocortical fasciculata cells
}

\author{
T Ebisawa, I Kondo ${ }^{1}$, E Masaki, S Hori and M Kawamura \\ Department of Pharmacology (I), Jikei University School of Medicine, 3-25-8 Nishi-Shinbashi, Minato-ku, Tokyo 105-8461, Japan \\ ${ }^{1}$ Department of Anesthesiology, Jikei University School of Medicine, 3-25-8 Nishi-Shinbashi, Minato-ku, Tokyo 105-8461, Japan \\ (Requests for offprints should be addressed to M Kawamura; Email: jkyakuri@sepia.ocn.ne.jp)
}

\begin{abstract}
Capacitative $\mathrm{Ca}^{2+}$ entry into bovine adrenocortical fasciculata cells was investigated by using the mobilization of intracellular $\mathrm{Ca}^{2+}$ concentration $\left(\left[\mathrm{Ca}^{2+}\right]_{\mathrm{i}}\right)$ and $\mathrm{Ca}^{2+}$ induced steroidogenesis as the indicators. Bovine adrenocortical fasciculata cells on a glass coverslip were loaded with fura-2. The $\left[\mathrm{Ca}^{2+}\right]_{\mathrm{i}}$ mobilization was detected by a change of fura-2 fluorescence intensity. In the intracellular $\mathrm{Ca}^{2+}$ store depleted cells, the addition of $\mathrm{Ca}^{2+}$ to the incubation medium elicited a marked and sustained increase in $\left[\mathrm{Ca}^{2+}\right]_{\mathrm{i}}$. In the intracellular $\mathrm{Ca}^{2+}$ store nondepleted cells, the addition of thapsigargin, an endoplasmic reticulum $\mathrm{Ca}^{2+}$-ATPase inhibitor, in the absence of extracellular $\mathrm{Ca}^{2+}$, induced a slight and transient increase in $\left[\mathrm{Ca}^{2+}\right]_{i}$, but an extensive and sustained increase in $\left[\mathrm{Ca}^{2+}\right]_{\mathrm{i}}$ was obtained by adding $\mathrm{Ca}^{2+}$ to the incubation
\end{abstract}

medium after the thapsigargin treatment. The sustained increase induced by thapsigargin was not inhibited by nifedipine, but was inhibited by $\mathrm{Zn}^{2+}$ and $\mathrm{Cd}^{2+}$ in a concentration-dependent manner. The effect of $\mathrm{Zn}^{2+}$ was more potent than that of $\mathrm{Cd}^{2+}$. Thapsigargin stimulated steroidogenesis in the presence of extracellular $\mathrm{Ca}^{2+}$. The steroidogenic effect of thapsigargin was inhibited by $\mathrm{Zn}^{2+}$ and $\mathrm{Cd}^{2+}$ but not by nifedipine.

These results suggest that there is, in bovine adrenocortical fasciculata cells, a steroidogenesis-linked $\mathrm{Ca}^{2+}$ entry process other than that involving voltage-operated $\mathrm{Ca}^{2+}$ channels and that the process might be capacitative $\mathrm{Ca}^{2+}$ entry.

Journal of Endocrinology (2000) 167, 473-478

\section{Introduction}

Adrenocorticotropic hormone (ACTH) stimulates adrenocortical fasciculata cells and facilitates glucocorticoid biosynthesis (steroidogenesis). It is well known that the steroidogenic effect of ACTH involves cyclic AMP production (Schimmer 1980). However, it was also proposed that $\mathrm{Ca}^{2+}$ was required for ACTH-induced steroidogenesis (Yanagibashi 1979). We previously showed that bovine adrenocortical fasciculata cells (BAFC) possess a voltage-operated calcium channel (VOC) and that ACTH activates the channel to enhance steroidogenesis (Yanagibashi et al. 1990). We also reported that extracellular adenosine $5^{\prime}$-triphosphate (ATP) facilitates steroidogenesis in BAFC via P2Y receptors (Kawamura et al. 1991). Niitsu (1992) has suggested that ATP induces $\mathrm{Ca}^{2+}$ influx via a dihydropyridine-insensitive pathway. Thus, ATP-induced steroidogenesis might be associated with a particular type of $\mathrm{Ca}^{2+}$ influx.

Recently, it has been reported that capacitative $\mathrm{Ca}^{2+}$ entry (i.e. $\mathrm{Ca}^{2+}$ entry triggered by depletion of intracellular $\mathrm{Ca}^{2+}$ stores) occurs in diverse non-excitable cells (Berridge 1995). Gq protein-coupled receptor agonists stimulate inositol 1,4,5-trisphosphate $\left(\mathrm{IP}_{3}\right)$ production and subsequent $\mathrm{Ca}^{2+}$ release from intracellular stores. Consequently, $\mathrm{Ca}^{2+}$ entry from an extracellular pool may arise (Putney \& Bird 1993).

In steroidogenic cells, it was reported that angiotensin II, which activates phospholipase C $\beta$ to increase intracellular $\mathrm{IP}_{3}$, stimulates aldosterone production via capacitative $\mathrm{Ca}^{2+}$ entry activation in bovine adrenocortical glomerulosa cells (Burnay et al. 1994). From these reports, we surmised that a capacitative $\mathrm{Ca}^{2+}$ entry was also involved in BAFC and was linked to glucocorticoid production.

In the present study, we investigated the involvement of a capacitative $\mathrm{Ca}^{2+}$ entry process in BAFC steroidogenesis.

\section{Materials and Methods}

Isolation and primary culture of $B A F C$

Isolated adrenocortical fasciculata cells were prepared aseptically from bovine adrenal cortex by use of collagenase and deoxyribonuclease I (DNase I) as described previously (Matsui 1991). Briefly, a minced adrenal cortex was incubated with collagenase $(0 \cdot 1 \%)$ and DNase I (0.005\%) in Krebs-Ringer bicarbonate buffer $(123.4 \mathrm{mM} \mathrm{NaCl}$, 
$5.9 \mathrm{mM} \quad \mathrm{KCl}, \quad 1.2 \mathrm{mM} \quad \mathrm{KH}_{2} \mathrm{PO}_{4}, 1.2 \mathrm{mM} \quad \mathrm{MgSO}_{4}$, $1.2 \mathrm{mM} \mathrm{CaCl}_{2}, 25 \mathrm{mM} \mathrm{NaHCO}_{3}, 2 \mathrm{mg} / \mathrm{ml}$ glucose, and $3 \mathrm{mg} / \mathrm{ml}$ bovine serum albumin; $\mathrm{pH} 7 \cdot 4$ ) for $1 \mathrm{~h}$ at $37^{\circ} \mathrm{C}$ under $95 \% \mathrm{O}_{2}-5 \% \mathrm{CO}_{2}$ as a gas phase. The cells were isolated by pipetting. The isolated cells were cultured in Ham's F-10 medium supplemented with 5\% fetal calf serum, $10 \%$ newborn calf serum, $2 \cdot 5 \%$ horse serum, and antibiotics. The 3-day cultured cells were used for the experiments.

\section{Measurement of intracellular concentration of $\mathrm{Ca}^{2+}$}

The determination of intracellular concentration of $\mathrm{Ca}^{2+}$ $\left(\left[\mathrm{Ca}^{2+}\right]_{\mathrm{i}}\right)$ in the monolayered BAFC on a glass coverslip coated with collagen was performed with the fluorescent probe fura-2 as described by Matsui (1991). Briefly, the cells were incubated with acetoxymethylester of fura-2 $(5 \mu \mathrm{M})$ for $1 \mathrm{~h}$ at $37^{\circ} \mathrm{C}$ in cremophor EL $(0.02 \%)$ containing Krebs-Ringer HEPES buffer $(123.4 \mathrm{mM} \mathrm{NaCl}$, $5.9 \mathrm{mM} \quad \mathrm{KCl}, 1.2 \mathrm{mM} \quad \mathrm{KH}_{2} \mathrm{PO}_{4}, 1.2 \mathrm{mM} \mathrm{MgSO}_{4}$, $1.2 \mathrm{mM} \mathrm{CaCl}, 10 \mathrm{mM}$ HEPES, $0.01 \mathrm{mM}$ EGTA and $2 \mathrm{mg} / \mathrm{ml}$ glucose; $\mathrm{pH}$ 7·4). The intracellular $\mathrm{Ca}^{2+}$ stores in BAFC could be diminished during the culture period, because Ham's F-10 medium contained $0.3 \mathrm{mM} \mathrm{Ca}{ }^{2+}$. The $\mathrm{Ca}^{2+}$ stores, however, might be refilled during the fura-2 loading process (i.e. Krebs-Ringer HEPES buffer is supplemented by $\left.1.2 \mathrm{mM} \mathrm{Ca}{ }^{2+}\right)$. Therefore, to diminish the intracellular $\mathrm{Ca}^{2+}$ stores in BAFC markedly, KrebsRinger HEPES buffer ( $\mathrm{pH} 7 \cdot 4$ ) which is not supplemented with $\mathrm{Ca}^{2+}$ was applied to the fura-2 loading period (the $\mathrm{Ca}^{2+}$-depleted cells). Fura-2-loaded BAFC were transferred to a quartz cuvette containing $\mathrm{Ca}^{2+}(-)$ HEPES buffer $(123.2 \mathrm{mM} \mathrm{NaCl}, 3 \mathrm{mM} \mathrm{KCl}, 1.2 \mathrm{mM}$ $\mathrm{NaH}_{2} \mathrm{PO}_{4}, 1 \cdot 2 \mathrm{mM} \mathrm{MgSO} 4,0.5 \mathrm{mM}$ EGTA $10 \mathrm{mM}$ HEPES and $2 \mathrm{mg} / \mathrm{ml}$ glucose; $\mathrm{pH} 7 \cdot 4$ ) and the concentrated $\mathrm{CaCl}_{2}$ and/or agents were added with continuous stirring. Fluorescence of the fura-2 loaded cells was monitored by Hitachi F-2000 fluorescence spectrophotometer (Hitachi, Japan) at $30{ }^{\circ} \mathrm{C}$ with continuous stirring at an emission wavelength of $510 \mathrm{~nm}$, while the excitation wavelength altered every $0.5 \mathrm{~s}$ between 340 and $380 \mathrm{~nm}$. $\left[\mathrm{Ca}^{2+}\right]_{\mathrm{i}}$ was shown as the ratio of the fluorescence intensity excited at $340 \mathrm{~nm}$ to that of $380 \mathrm{~nm}\left(I_{340} / I_{380}\right)$.

\section{Measurement of steroidogenesis}

Cortisol production by monolayered BAFC on a 24-well type dish $\left(15-20 \times 10^{4}\right.$ cells/well) was measured. BAFC were incubated in the low $\mathrm{K}^{+}$-Krebs-Ringer bicarbonate buffer (123.4 mM NaCl, $3 \mathrm{mM} \mathrm{KCl}, 1.2 \mathrm{mM} \mathrm{NaH}_{2} \mathrm{PO}_{4}$, $1.2 \mathrm{mM} \mathrm{MgSO}, 25 \mathrm{mM} \mathrm{NaHCO}, 3.01 \mathrm{mM}$ EGTA, $2 \mathrm{mg} / \mathrm{ml}$ glucose and $3 \mathrm{mg} / \mathrm{ml}$ bovine serum albumin; $\mathrm{pH} 7 \cdot 4$ ) with or without $1.2 \mathrm{mM} \mathrm{Ca}^{2+}$ for $1 \mathrm{~h}$ at $37^{\circ} \mathrm{C}$ in a humidified atmosphere at $5 \% \mathrm{CO}_{2}$ in air. Steroid in the incubation medium was determined fluorometrically by use of cortisol as a standard (Salvinski et al. 1976). The sensitivity of the method was $1 \mathrm{ng}$, and the intra- and inter-assay coefficient variations were $2 \cdot 1 \%$ and $3 \cdot 1 \%$ respectively.

\section{Statistics}

Analysis of variance and Student's $t$-test were used for the statistical analysis of the data. The value of $P<0.05$ was considered to be statistically significant.

\section{Materials}

The materials were purchased from the following: collagenase from Funakoshi (Tokyo, Japan); DNase I, nifedipine and thapsigargin (TG) from Sigma Chemical Co. (St Louis, MO, USA); fura-2/AM from Dojindo (Kumamoto, Japan); Ham's F-10 medium from Gibco Laboratories Inc. (New York, USA). All the other chemicals were of reagent grade.

\section{Results}

Effect of the intracellular $\mathrm{Ca}^{2+}$ store depletion on $\mathrm{Ca}^{2+}$ entry

We first examined the effect of the extracellular addition of $\mathrm{Ca}^{2+}$ on $\mathrm{Ca}^{2+}$ entry in fura-2 loaded BAFC. Fura-2 was loaded in BAFC in the absence (the $\mathrm{Ca}^{2+}$-depleted cells) and presence (the $\mathrm{Ca}^{2+}$-non-depleted cells) of $1.2 \mathrm{mM}$ $\mathrm{Ca}^{2+}$ for $1 \mathrm{~h}$ at $37^{\circ} \mathrm{C}$. After that $\left[\mathrm{Ca}^{2+}\right]_{\mathrm{i}}$ in the fura-2 loaded cells on a glass coverslip was determined in $\mathrm{Ca}^{2+}(-)$ HEPES buffer ( $\mathrm{pH} 7 \cdot 4)$. In the $\mathrm{Ca}^{2+}$-non-depleted cells, the addition of $2.4 \mathrm{mM} \mathrm{Ca}^{2+}$ caused only a slight increase in $\left[\mathrm{Ca}^{2+}\right]_{\mathrm{i}}$ (Fig. 1A). However, in $\mathrm{Ca}^{2+}$-depleted BAFC, the addition of $2.4 \mathrm{mM} \mathrm{Ca}^{2+}$ triggered a significant and immediate increase in $\left[\mathrm{Ca}^{2+}\right]_{\mathrm{i}}$ (Fig. 1B). The effect of added $\mathrm{Ca}^{2+}$ was concentration-dependent, and reached a maximum at $1.2 \mathrm{mM} \mathrm{Ca}^{2+}$ (data not shown). The results suggest that the depletion of intracellular $\mathrm{Ca}^{2+}$ stores elicits a $\mathrm{Ca}^{2+}$ flux from the extracellular pool in BAFC.

As shown in Fig. 2A, $30 \mathrm{mM} \mathrm{K}^{+}$induced a rapid increase in $\left[\mathrm{Ca}^{2+}\right]_{\mathrm{i}}$ and an ensuing sustained rise in $\left[\mathrm{Ca}^{2+}\right]_{\mathrm{i}}$. Nifedipine $(10 \mu \mathrm{M})$, a VOC-selective antagonist, inhibited the sustained phase. However, $10 \mu \mathrm{M}$ nifedipine inhibited the $\mathrm{Ca}^{2+}$ entry induced by $2.4 \mathrm{mM} \mathrm{Ca}^{2+}$ only slightly in the $\mathrm{Ca}^{2+}$-depleted cells (Fig. 2B). However, because the low $\mathrm{K}^{+}(3 \mathrm{mM})$ buffer was used in the experiment to avoid the contribution of VOC to $\left[\mathrm{Ca}^{2+}\right]_{\mathrm{i}}$ mobilization, the result suggests that VOC may be involved in a small part of the $\mathrm{Ca}^{2+}$ entry produced by the addition of extracellular $\mathrm{Ca}^{2+}$.

\section{Effect of TG on $\mathrm{Ca}^{2+}$ entry}

In order to deplete intracellular $\mathrm{Ca}^{2+}$ stores extensively, we treated BAFC with $2 \mu \mathrm{M}$ TG, which inhibits the 
A

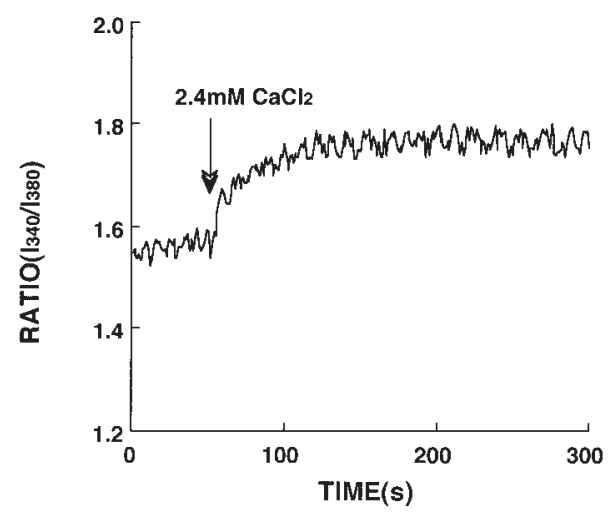

B

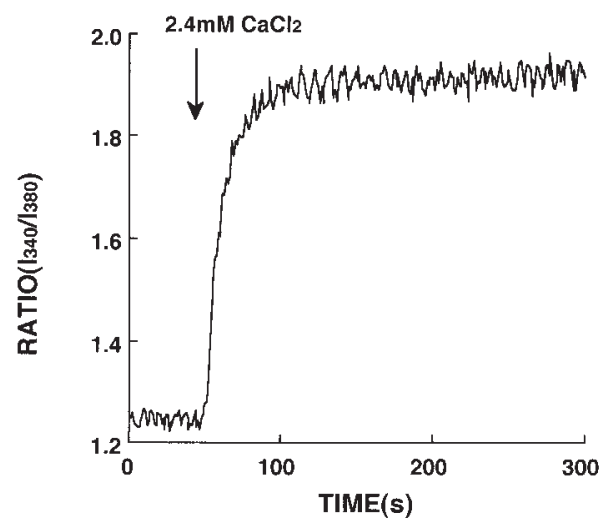

Figure 1 Effect of the extracellular addition of $\mathrm{Ca}^{2+}$ on $\left[\mathrm{Ca}^{2+}\right]_{i}$ mobilization in $\mathrm{Ca}^{2+}$-depleted BAFC. (A) The $\mathrm{Ca}^{2+}$-non-depleted cells. (B) The $\mathrm{Ca}^{2+}$-depleted cells. Each trace is representative of five to ten experiments, yielding qualitatively similar results.

A

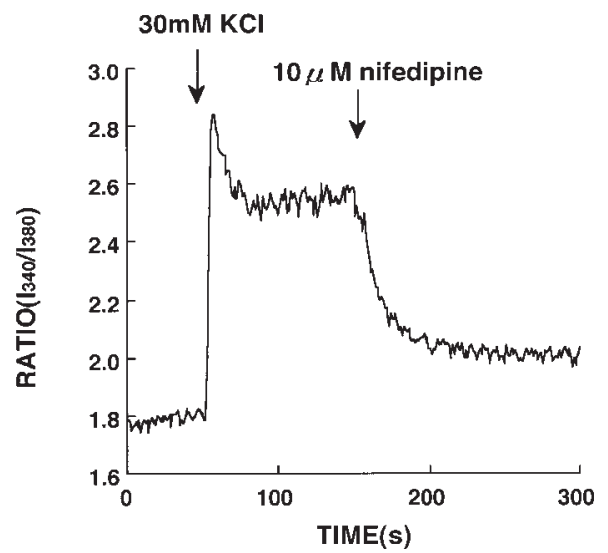

B

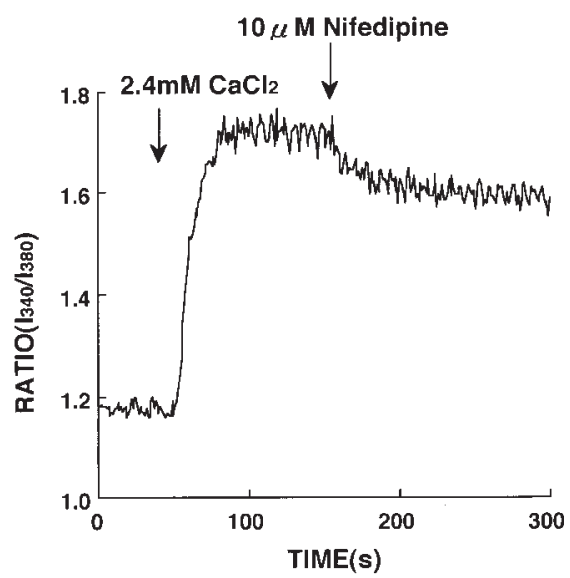

Figure 2 Effect of nifedipine on $\left[\mathrm{Ca}^{2+}\right]_{\mathrm{i}}$ mobilization induced by $30 \mathrm{mM} \mathrm{K}$ and $\mathrm{Ca}^{2+}$ store depletion in BAFC. (A) BAFC on a glass coverslip were loaded with fura-2/AM in Krebs-Ringer HEPES buffer $(\mathrm{pH} 7 \cdot 4)$ supplemented with $1.2 \mathrm{mM} \mathrm{Ca}^{2+}$ at $37^{\circ} \mathrm{C}$ for $1 \mathrm{~h}$. $\mathrm{KCl}$ was added $50 \mathrm{~s}$ after the beginning of fluorescence determination. (B) BAFC on a glass coverslip were loaded with fura-2/AM in Krebs-Ringer HEPES buffer $(\mathrm{pH} 7 \cdot 4)$ in the absence of $\mathrm{Ca}^{2+}$ at $37^{\circ} \mathrm{C}$ for $1 \mathrm{~h} . \mathrm{CaCl}_{2}$ was added $50 \mathrm{~s}$ after the beginning of fluorescence determination. Each trace is representative of three to five experiments, yielding qualitatively similar results.

$\mathrm{Ca}^{2+}$-ATPase on endoplasmic reticulum (ER) (Thatrup et al. 1989). As shown in Fig. 3A, adding $2 \mu \mathrm{M}$ TG in $\mathrm{Ca}^{2+}(-)$ HEPES buffer caused a transient rise in $\left[\mathrm{Ca}^{2+}\right]_{\mathrm{i}}$ and thereafter $\left[\mathrm{Ca}^{2+}\right]_{\mathrm{i}}$ declined gradually to basal level. The addition of $2.4 \mathrm{mM} \mathrm{Ca}^{2+}$ extracellularly after TG treatment caused a significant sustained rise in $\left[\mathrm{Ca}^{2+}\right]_{\mathrm{i}}$ (Fig. 3). This effect of $\mathrm{Ca}^{2+}$ addition was not inhibited by $10 \mu \mathrm{M}$ nifedipine (data not shown) but was inhibited markedly by $\mathrm{Zn}^{2+}$ and $\mathrm{Cd}^{2+}$ (Fig. 3A,B). The effects of $\mathrm{Zn}^{2+}$ and $\mathrm{Cd}^{2+}$ were concentration-dependent and the effect of $\mathrm{Zn}^{2+}$ was more potent than that of $\mathrm{Cd}^{2+}$ (Fig. 4). $\mathrm{Ni}^{2+}$ showed only a weak inhibitory effect on the $\left[\mathrm{Ca}^{2+}\right]_{\mathrm{i}}$ mobilization (data not shown).
The dependence of steroidogenesis on extracellular $\mathrm{Ca}^{2+}$

We previously reported that steroidogenesis was facilitated by the entry of $\mathrm{Ca}^{2+}$ from an extracellular pool as well as by cyclic AMP (Yanagibashi et al. 1990). We therefore examined the steroidogenic effect of TG treatment in BAFC. Though the addition of $1.2 \mathrm{mM} \mathrm{Ca}^{2+}$ stimulated cortisol production only slightly in the absence of $\mathrm{TG}$, the addition of $1.2 \mathrm{mM} \mathrm{Ca}^{2+}$ to the TG-treated cells caused marked steroidogenic activity (Fig. 5). The effect of $\mathrm{Ca}^{2+}$ in the TG-treated cells was inhibited significantly by $1 \mathrm{mM} \mathrm{Zn}^{2+}$ and $1 \mathrm{mM} \mathrm{Cd}^{2+}$, but not by $1 \mu \mathrm{M}$ nifedipine (Fig. 6). The tested concentration of nifedipine inhibited 
A

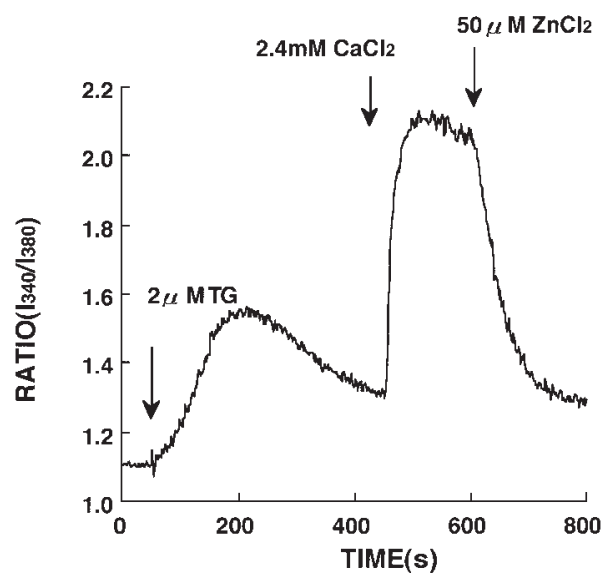

B

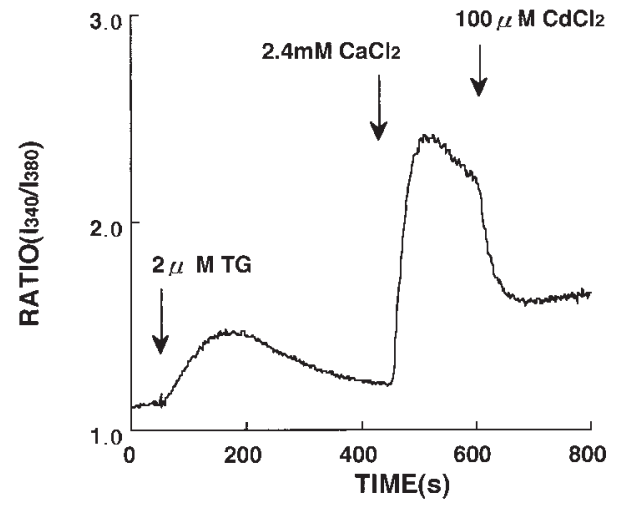

Figure 3 Effects of $\mathrm{Zn}^{2+}$ and $\mathrm{Cd}^{2+}$ on $\mathrm{Ca}^{2+}$ entry in TG-treated BAFC. TG $(2 \mu \mathrm{M})$ was added $50 \mathrm{~s}$ after the

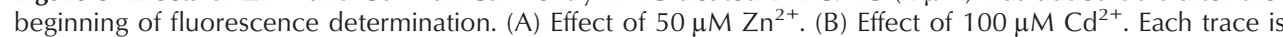
representative of four experiments, yielding qualitatively similar results.

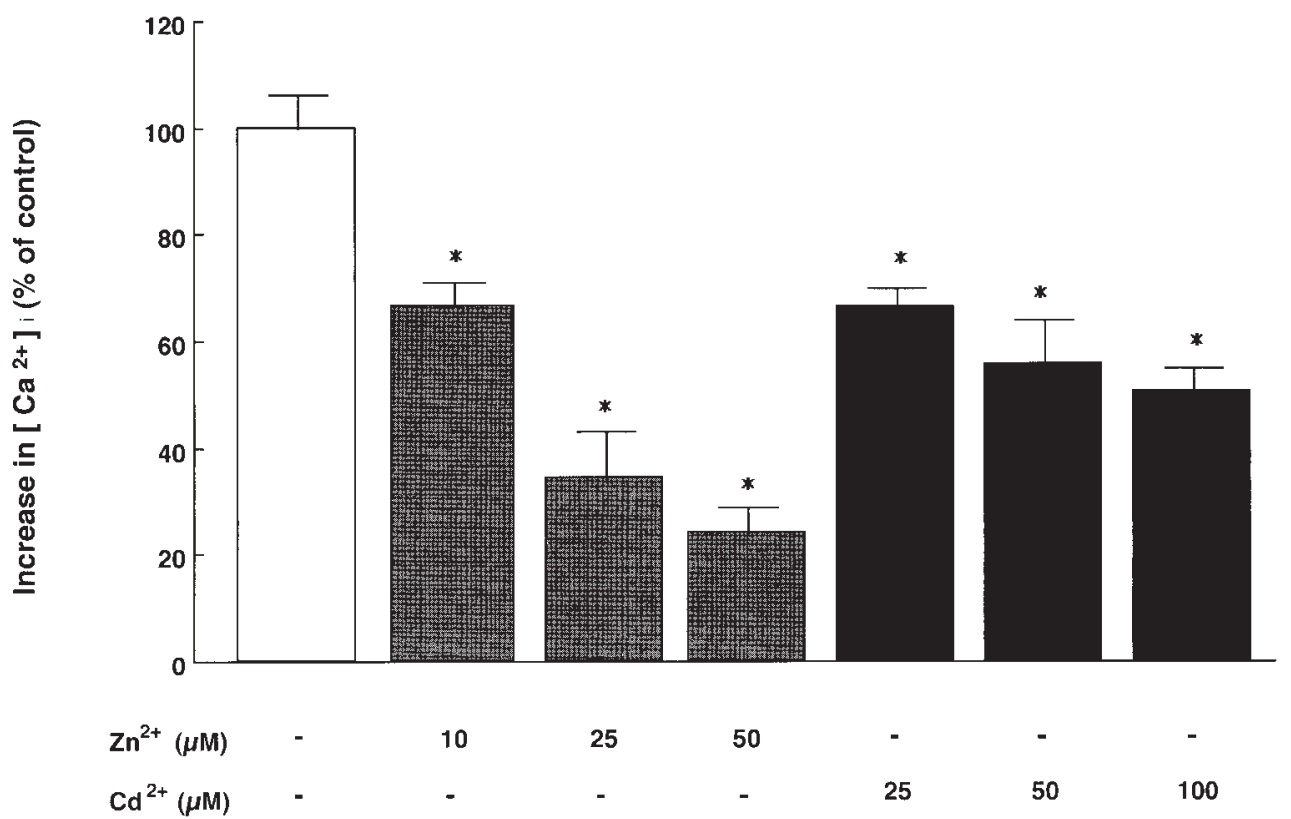

Figure 4 Effects of $\mathrm{Zn}^{2+}$ and $\mathrm{Cd}^{2+}$ on TG $(2 \mu \mathrm{M})$-induced increase in $\left[\mathrm{Ca}^{2+}\right]_{\mathrm{i}}$ in BAFC. The increase in $\left[\mathrm{Ca}^{2+}\right]_{\mathrm{i}}$ was determined as the distance from the basal level at $600 \mathrm{~s}$, and represented the percentage of the value in the absence of each antagonist. Each column represents the mean \pm S.D. from four separate experiments. *Significantly different from the control value $(P<0 \cdot 01)$.

high $\mathrm{K}^{+}$-induced steroidogenesis completely in isolated bovine adrenocortical cells (Yanagibashi et al. 1990).

\section{Discussion}

The present experiments strongly suggest capacitative $\mathrm{Ca}^{2+}$ entry occurs in BAFC and that this process participates in the regulation of glucocorticoid production.
So far, a selective antagonist of capacitative $\mathrm{Ca}^{2+}$ entry is not yet available. However, Hoth \& Penner (1993) reported a $\mathrm{Ca}^{2+}$ current associated with store depletion (a $\mathrm{Ca}^{2+}$ release-activated $\mathrm{Ca}^{2+}$ current; $\mathrm{I}_{\mathrm{CRAC}}$ ) in rat peritoneal mast cells different from other plasma membrane $\mathrm{Ca}^{2+}$ entry pathways. They showed that $\mathrm{I}_{\mathrm{CRAC}}$ was inhibited by divalent cations with a potency order of $\mathrm{Zn}^{2+}>\mathrm{Cd}^{2+}>>\mathrm{Ni}^{2+}$. In the $\mathrm{Ca}^{2+}$ store-depleted BAFC, 


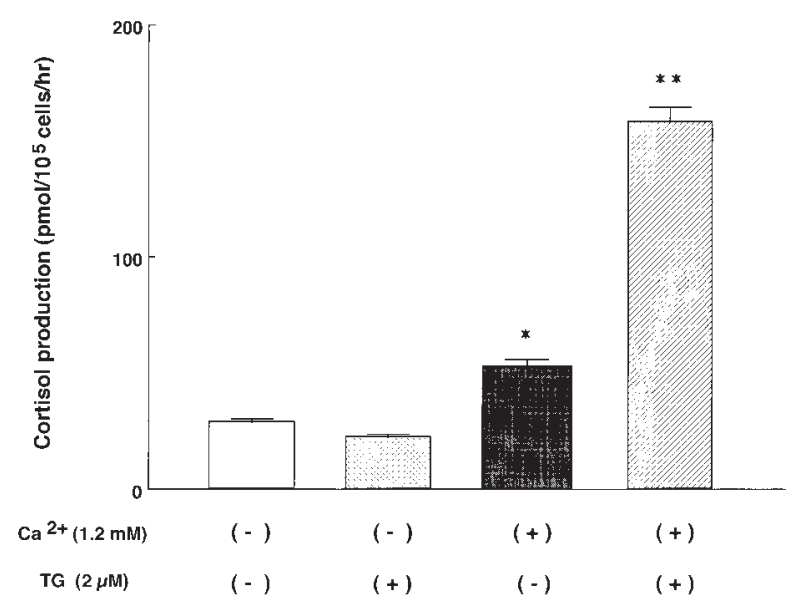

Figure 5 Effects of the extracellular $\mathrm{Ca}^{2+}$ and TG $(2 \mu \mathrm{M})$ on steroidogenesis in BAFC. BAFC were incubated in low $\mathrm{K}^{+}$-KrebsRinger bicarbonate buffer $(\mathrm{pH} 7 \cdot 4)$ either supplemented with or without $1 \cdot 2 \mathrm{mM} \mathrm{Ca}^{2+}$ in the presence or absence of TG at $37^{\circ} \mathrm{C}$ for $1 \mathrm{~h}$. Each column represents the mean \pm S.D. from three separate experiments. ${ }^{*} * *$ Significantly different from steroidogenesis at the $\mathrm{Ca}^{2+}(-)$ condition $\left({ }^{*} P<0 \cdot 05,{ }^{* *} P<0 \cdot 01\right)$.

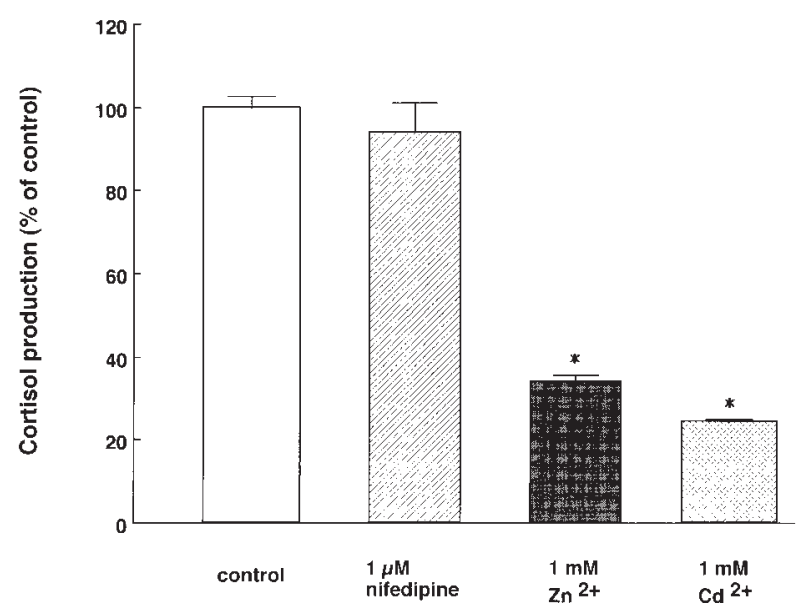

Figure 6 Effects of nifedipine, $\mathrm{Zn}^{2+}$ and $\mathrm{Cd}^{2+}$ on TG $(2 \mu \mathrm{M})$-induced steroidogenesis in BAFC. The incubation medium was low $\mathrm{K}^{+}-$Krebs-Ringer bicarbonate buffer $(\mathrm{pH} 7 \cdot 4)$ supplemented with $1 \cdot 2 \mathrm{mM} \mathrm{Ca}^{2+}$. The values represent per cent of $2 \mu \mathrm{M}$ TG-induced cortisol production (control). Each column represents the mean \pm S.D. from three separate experiments. *Significantly different from the control value $(P<0 \cdot 01)$.

$\mathrm{Zn}^{2+}, \mathrm{Cd}^{2+}$ and $\mathrm{Ni}^{2+}$ inhibited a significant sustained rise in $\left[\mathrm{Ca}^{2+}\right]_{\mathrm{i}}$ induced by the addition of extracellular $\mathrm{Ca}^{2+}$ and TG at the same potency order as reported by Hoth \& Penner (1993). Our results of the inhibitory effects of these cations on $\left[\mathrm{Ca}^{2+}\right]_{\mathrm{i}}$ mobilization are in agreement with those of Hoth \& Penner (1993), and suggest a similar mechanism is involved in BAFC.

Yanagibashi et al. (1990) showed that the steroidogenic effect of ACTH in the presence of extracellular $\mathrm{Ca}^{2+}$ was completely abolished by dihydropyridines in freshly isolated bovine adrenocortical cells. They proposed the existence of a VOC which was activated by ACTH in BAFC. Our result also suggests the presence of VOC in BAFC. However, we used the low $\mathrm{K}^{+}$concentration buffer in the experiments to avoid the contribution of VOC to $\left[\mathrm{Ca}^{2+}\right]_{i}$ mobilization. Therefore, in our experimental conditions, a capacitative $\mathrm{Ca}^{2+}$ entry process must have been activated in BAFC.

The TG treatment accelerated cortisol production remarkably in the presence of extracellular $\mathrm{Ca}^{2+}$ but did not in its absence. TG-induced steroidogenesis is inhibited by $\mathrm{Zn}^{2+}$ and $\mathrm{Cd}^{2+}$, but a dihydropyridine derivative did not attenuate the steroidogenic effect of TG. This effect of TG on steroidogenesis was consistent with the observation of TG-induced $\mathrm{Ca}^{2+}$ entry. Steroidogenesis due to the TGinduced $\mathrm{Ca}^{2+}$ entry in BAFC was not involved in VOC. As described above, TG activates $\mathrm{Ca}^{2+}$ influx from an extracellular pool via capacitative $\mathrm{Ca}^{2+}$ entry in BAFC. These results indicate that BAFC contain a capacitative $\mathrm{Ca}^{2+}$ entry process which is linked to steroidogenesis. However, the physiological role of the capacitative $\mathrm{Ca}^{2+}$ entry in glucocorticoid biosynthesis remains obscure. In BAFC, extracellular ATP stimulates the release of $\mathrm{Ca}^{2+}$ from the intracellular $\mathrm{Ca}^{2+}$ stores to cause $\mathrm{Ca}^{2+}$ influx from an extracellular pool (Matsui 1991) and facilitates steroidogenesis via P2Y receptors (Kawamura et al. 1991), which is not inhibited by dihydropyridine (Niitsu 1992). Therefore ATP-induced steroidogenesis might be activated by capacitative $\mathrm{Ca}^{2+}$ entry. In bovine adrenal glomerulosa cells, the major part of aldosterone biosynthesis by angiotensin II involves capacitative $\mathrm{Ca}^{2+}$ entry initiated by angiotensin II-induced release of $\mathrm{Ca}^{2+}$ from intracellular stores (Burnay et al. 1994). ATP and angiotensin II both activate phospholipase $\mathrm{C} \beta$ and release $\mathrm{IP}_{3}$ and diacylglycerol via $\mathrm{P} 2 \mathrm{Y}$ and angiotensin II receptors respectively (Bird et al. 1989, Bollag et al. 1991, Boarder et al. 1995).

These results suggest that there are at least two pathways involved in $\mathrm{Ca}^{2+}$ entry in BAFC: one is VOC and the other is capacitative $\mathrm{Ca}^{2+}$ entry. The mechanism of capacitative $\mathrm{Ca}^{2+}$ entry in BAFC still remains to be elucidated.

\section{Acknowledgements}

We thank Drs S G Hillier and Ashraf Ahmed for critical reading of this manuscript, Dr Haruhisa Nishi for his statistical analysis of the data, Ms Miyuki Kagata for technical assistance and typing the manuscript, and also Ms Chieko Gido for technical assistance. 


\section{References}

Berridge MJ 1995 Capacitative calcium entry. Biochemical Journal 312 $1-11$.

Bird IM, Meikle I, Williams BC \& Walker SW 1989 Angiotensin II-stimulated cortisol secretion is mediated by a hormone-sensitive phospholipase $\mathrm{C}$ in bovine adrenal fasciculata/reticularis cells. Molecular and Cellular Endocrinology 64 45-53.

Boarder MR, Weisman GA, Turner JT \& Wilkinson GF 1995 G protein-coupled P2 purinoceptors: from molecular biology to functional responses. Trends in Pharmacological Science 16 133-139.

Bollag WB, Barrett PQ, Isales CM \& Rasmussen H 1991 Angiotensin-II-induced changes in diacylglycerol levels and their potential role in modulating the steroidogenic response. Endocrinology 128 231-241.

Burnay MM, Python CP, Vallotton MB, Capponi AM \& Rossier MF 1994 Role of the capacitative calcium influx in the activation of steroidogenesis by angiotensin-II in adrenal glomerulosa cells. Endocrinology 135 751-758.

Hoth M \& Penner R 1993 Calcium release-activated calcium current in rat mast cells. Journal of Physiology 465 359-386.

Kawamura M, Matsui T, Niitsu A, Kondo T, Ohno Y \& Nakamichi N 1991 Extracellular ATP stimulates steroidogenesis in bovine adrenocortical fasciculata cells via P2 purinoceptors. Japanese Journal of Pharmacology 56 543-545.

Matsui T 1991 Biphasic rise caused by extracellular ATP in intracellular calcium concentration in bovine adrenocortical fasciculata cells. Biochemical and Biophysical Research Communications 178 1266-1272.
Niitsu A 1992 Calcium is essential for ATP-induced steroidogenesis in bovine adrenocortical fasciculata cells. Japanese Journal of Pharmacology 60 269-274.

Putney JW Jr \& Bird GSJ 1993 The inositol phosphate-calcium signaling system in nonexcitable cells. Endocrine Review $\mathbf{1 4}$ 610-631.

Salvinski EA, Jull JW \& Auersberg N 1976 Steroidogenic pathway and trophic response to adrenocorticotrophin of cultured adrenocortical cells in different states of differentiation. Journal of Endocrinology 69 385-394.

Schimmer BP 1980 Cyclic nucleotides in hormonal regulation of adrenocortical function. Advances in Cyclic Nucleotide Research 13 181-214.

Thatrup O, Dawson AP, Scharff O, Foder B, Cullen PJ, Drobak BK, Bjerrum PT, Christensen SB \& Hanley MR 1989 Thapsigargin, a novel molecular probe for studying intracellular calcium release and storage. Agents and Actions 27 17-23.

Yanagibashi K 1979 Calcium ion as 'second messenger' in corticoidogenic action of ACTH. Endocrinologia Japonica 26 227-232.

Yanagibashi K, Kawamura M \& Hall PF 1990 Voltage-dependent $\mathrm{Ca}^{2+}$ channels are involved in regulation of steroid synthesis by bovine but not rat fasciculata cells. Endocrinology 127 311-318.

Received 20 December 1999

Revised manuscript received 21 July 2000

Accepted 15 August 2000 